\section{Pakistan's ambitious nuclear power programme}

\section{from Azim Kidwai, Karachi}

TWENTY-FOUR nuclear power plants operational in a developing country by the end of the century seems too ambitious a programme in the present global context, but that is the plan at the drawing-board stage in Pakistan. Work on a second nuclear plant, at Chashma Barrage, on the river Indus, 150 miles south of Islamabad, starts in a few months' time. The project is estimated to cost Rupees 527 crores (527 million dollars). The 137-MW nuclear power plant at Karachi has been in commercial operation for the past five years. The Chairman of the Pakistan Atomic Energy Commission (PAEC), Mr Munir Ahmad Khan unfolded the revised crash plan for 24 nuclear power plants recently, in the wake of a bilateral agreement with France that includes the offer by the French of a nuclear reprocessing plant (cost 150 million dollars) for Pakistan.

The rationale for such an unorthodox accelerated nuclear power programme can perhaps be found in the poor energy resources of the country, coupled with the present very low per capita electrical energy consumption.

The known fuel resources in Pakis$\tan$ have been estimated to be only 13 tons coal equivalent (TCE) per capita. The figure presents a dismal picture when viewed against the world average per capita resources of 1,200 TCE. Similarly, the per capita electrical power consumption in Pakistan at present stands at $140 \mathrm{kWh}$ as against $1,360 \mathrm{kWh}$ world average, which has been extrapolated to be $6,500 \mathrm{kWh}$ by the end of the century.

The requirements at the close of the century have been estimated at $27,000 \mathrm{MW}$ (current production is only 2,570 MW, and the huge Tarbela Dam will soon add another $2,000 \mathrm{MW}$ ). Hydropower and gas-the only two energy sources of consequence in Pakistan - could only supply $13,500 \mathrm{MW}$. There seems not much of an option left, since planning on imports of huge quantities of oil would be hazardous. The main argument of PAEC, though, is that "the nuclear power plant's fuelling would be much cheaper than those of oil fired plants. The generation cost of a nuclear power plant would be $33 \%$ cheaper than that of a conventional power plant". In the long run, seen against the recent oil crisis, the argument appears to have validity even taking the higher capital costs of nuclear power plants into consideration.
All this planning on nuclear power may undergo revision if oil is struck in large quantities in Pakistan. Tremendous efforts are on the way as the 1976-77 budget on oil exploration at Rupees 42 crores (42 million dollars) testifies. The allocation has been more than doubled as compared to the figures in the current year. But without oil, the main plank of energy strategy in Pakistan will have to be nuclear because of the good deposits of uranium discovered recently in Pakistan and soon to be exploited. Concerted efforts to locate more uranium deposits also continue. Some of the areas have also been found with sizeable extents of thorium-bearing mineralisation-this fits into Pakistani nuclear think-tank schemes which envisage branching off to thorium.

One nuclear plant each year, on average, is planned after the early 1980s. The scheme includes dual-purpose nuclear plants as well. For instance, feasibility studies on such a dual-purpose nuclear plant for Karachi were mounted some time back in which the city could add to its grid another $400 \mathrm{MWe}$ by the early $1980 \mathrm{~s}$ and could also augment its water supply by 100 million gallons of sweet water from the sea daily.

Such a vast programme of nuclear power development calls for considerable manpower with sophisticated technical know-how. The PAEC has been training a large number of scientists and engineers for the last decade to meet the present situation. There are already some 350 scientists and engineers trained abroad on the rolls of the PAEC and a large number have been or are being trained at the Reactor School at Nilore near Islamabad. Another big nuclear power training centre which will cost Rupees 2.5 crores is being planned. Based at Karachi, and designed to train about 200 persons including technicians and operators annually, the centre would fill the gap on the technical manpower requirements of the $\mathrm{PAEC}$ in the coming years.

\section{USSR's polar research}

from Vera Rich

Arctic and Antarctic research has long been a major field of Soviet research. Indeed, the establishment of the first Severnyi Polyus (North Pole) drifting ice-floe research station and the forcing of the North East Passage by an icebreaker in the 1930's had at that time much of the prestige value now associated with the space programme. This sense of the spectacular is still sometimes apparent in the announce- ment of new Soviet Arctic projects.

The "Polar Experiment North-76" from April to July this year, for example, was announced as the "largest comprehensive expedition in the history of Arctic exploration", involving ten research vessels (including the flagship Professor Vize), aircraft, and upper atmosphere probe rockets. According to Professor A. Treshnikov, Director of the Arctic and Antarctic Institute (Leningrad), the principal aim of the expedition is to calculate the thermal balance of the Arctic icecap simultaneously on land, in the ocean, in the atmosphere and on the drift-ice (including observations at the North Pole itself). The data gathered during the 100-day expedition will be used to formulate mathematical models of hydrological and meteorological processes for use in weather forecasting. The expedition is envisaged as the first in a series to take place at oneand two-yearly intervals as part of a programme sponsored by the World Meteorological Organization.

Results of the previous voyage of the Professor Vize are meanwhile being processed. That expedition, during the Antarctic summer of 1975-76, produced data indicating that the Antarctic circumpolar current is "equal in flow to six Gulf Streams". The research vessel Dmitrii Mendeleev also visited the Antarctic during the same summer on its first biological expedition. According to the expedition leader, Dr L. A. Ponomareva, its programme included research into the fauna of the ocean bed, the sampling of water from the bottom layers of the Macquarie complex, study of the Macquarie and Hjort trenches, the collection of sedimentary and geological material and the construction of plankton profiles south from New Zealand and Tasmania to the Antarctic ice.

Also back from the Antarctic is the Twentieth Soviet Antarctic Expedition. The programme of this expedition appears to have followed the usual pattern of meteorological and glaciological observations. Innovations included the automated processing of data obtained from upper atmosphere rockets-the first time, it is claimed, that this has been done under Antarctic conditions-and a new way of drilling glaciers using a borehole filled with a "non-freezing liquid". Drilling at the Vostok station was carried out to $450 \mathrm{~m}$, and at the Novolazarevskii station (where no previous bores had been made) to $357 \mathrm{~m}$-the total thickness of the icecap at this point. The TASS agency hailed this expedition as a notable achievement in international cooperation: it included medical workers and geodesists from East Germany; an American geologist 